\title{
The Congo National Parks Since Independence
}

$$
\text { By Kai Curry-Lindahl }
$$

With the collapse of all government in the Congo on the declaration of independence in June, 1960, it seemed almost impossible that the national parks, and in particular the large Albert Park with its sanctuary for the rare mountain gorilla, could survive intact. How, despite all the chaos, difficulties and dangers, the impossible was achieved, is described by Dr. Curry-Lindahl, Director of the Natural Sciences Department of the Nordiska Museum and Skansen in Stockholm, who has done extensive work on vertebrate ecology in the Congo and knows the parks well.

VYHEN the Belgian Congo became independent on 30th June, 1960, almost everything in the country passed into turmoil. Government collapsed, law and order were undermined, and most of the scientific institutions ceased to function. As the situation became more and more chaotic, almost the whole world expected that the national parks would collapse too. How could such enormous and vulnerable institutions remain intact in such an unstable situation ? The Congo parks have been strict natural reserves without human interference since they were created, and it was feared that political and social pressure would end this policy. Wild rumours circulated: that the parks had been invaded by surrounding populations, that the rangers had abandoned their posts, that much poaching was going on, with terrific slaughter of game and so on. Fortunately very little of this was true, although the Congolese national parks passed through many dramatic events.

Of the three Congo parks the Albert National Park is the most famous. It is the oldest national park in Africa, created in 1925 with the main aim of forming a sanctuary for the mountain gorillas in the Virunga volcanoes. In 1929 and again in 1935 it was greatly extended until it covered 809,000 hectares. It has an extraordinary diversity of habitats ranging from the equatorial lowland rain forest at a level of $798 \mathrm{~m}$. above sea level up to the eternal snow and glaciers on the Ruwenzori at $5,119 \mathrm{~m}$. This altitudinal range of about $4,300 \mathrm{~m}$. gives the Albert National Park a representative series of different types of climate as well as a variety of vegetation zones. Straddling the Equator, the park embraces large and small lakes at various levels, marshes, bogs, rivers, different types of savannas and forests, all montane vegetation belts, extinct and living volcanoes, hot springs, lava plains and non-volcanic mountains (Ruwenzori). Moreover, the two largest lakes of the Albert National Park belong to different water systems, Lake Kivu to the Congo basin and Lake Edward to the Nile system. In fact, the Albert National Park covers almost all main habitats of tropical Africa except deserts, semi-deserts and marine biotopes. In this remarkably rich complex of habitats there are many plant and animal species with 
endemic or restricted distribution, the best known being the mountain gorilla Gorilla gorilla beringei, which lives in the Virunga volcanoes.

The great value of the Albert National Park is that the whole area with its wide range of biocoenoses can be regarded as a kind of super ecosystem, where man does not interfere. It is a gigantic natural experimental field. As such it is unique and has immense scientific value, which, in the long run, is also of economic benefit, because it offers examples of bioproductivity and shows how different biocommunities evolve in natural stages. It helps us to understand how in tropical Africa man can, in an ecologically sound way, co-operate with nature instead of fighting it. This is of great importance for the future of man in Africa. The park has a tremendously high biomass per square kilometre far superior to that of cultivated pastures (Bourlière and Verschuren, 1960). It is sufficiently large to be considered as " bioindependent " as long as its water supply, which comes partly from rivers outside the reserve, remains untouched by man. Consequently, it is vitally important to keep the park intact. It is still a kind of virgin landscape, although in the past the savannas were modified by man's burning.

\section{Research in a Strict Nature Reserve}

The policy of strict natural reserve in the Congolese national parks was adopted at an early stage of their creation and has since been carefully adhered to, though some minor areas in two of the parks (Albert and Upemba) have been opened for tourism. Scientific research has always been very intensive in the parks and a wealth of material has been collected and described in several impressive series of publications. No areas in the tropics comparable in size to the Congo in general and its national parks in particular have been studied scientifically as thoroughly as those lying within the former Belgian territories in Africa. It is only fair to give Belgium full credit and recognition for its marvellous work in conservation and natural science research in the Congo.

In this respect one must pay special tribute to one particular man, a giant in the work of nature conservation in Africa, Professor Victor Van Straelen, who died recently. President of the Institute of the National Parks of the Congo and Ruanda-Burundi since its foundation, Professor Van Straelen defended Africa's threatened wildlife brilliantly and energetically and showed a remarkable foresight combined with ability to understand both past and present.

In July, 1960, as chaos spread rapidly in the Congo, intensified by the revolt of the soldiers, the Albert National Park was seriously menaced in many ways. When the military revolt broke out, the garrison near Rumangabo, the park headquarters in its southern sector, immediately captured their officers and turned against the park officials and rangers, who were militarily organised and regarded as government administrators, which, in fact, they were, although by then under the Congolese government. In the conflict with the soldiers the park staff received no support from either central or provincial government. They were captured and assaulted by the soldiers and, finally, threatened with immediate execution. The Belgian troops, who had arrived in the Congo at the request of the Congolese Foreign Minister, had no time to restore order in the Kivu 


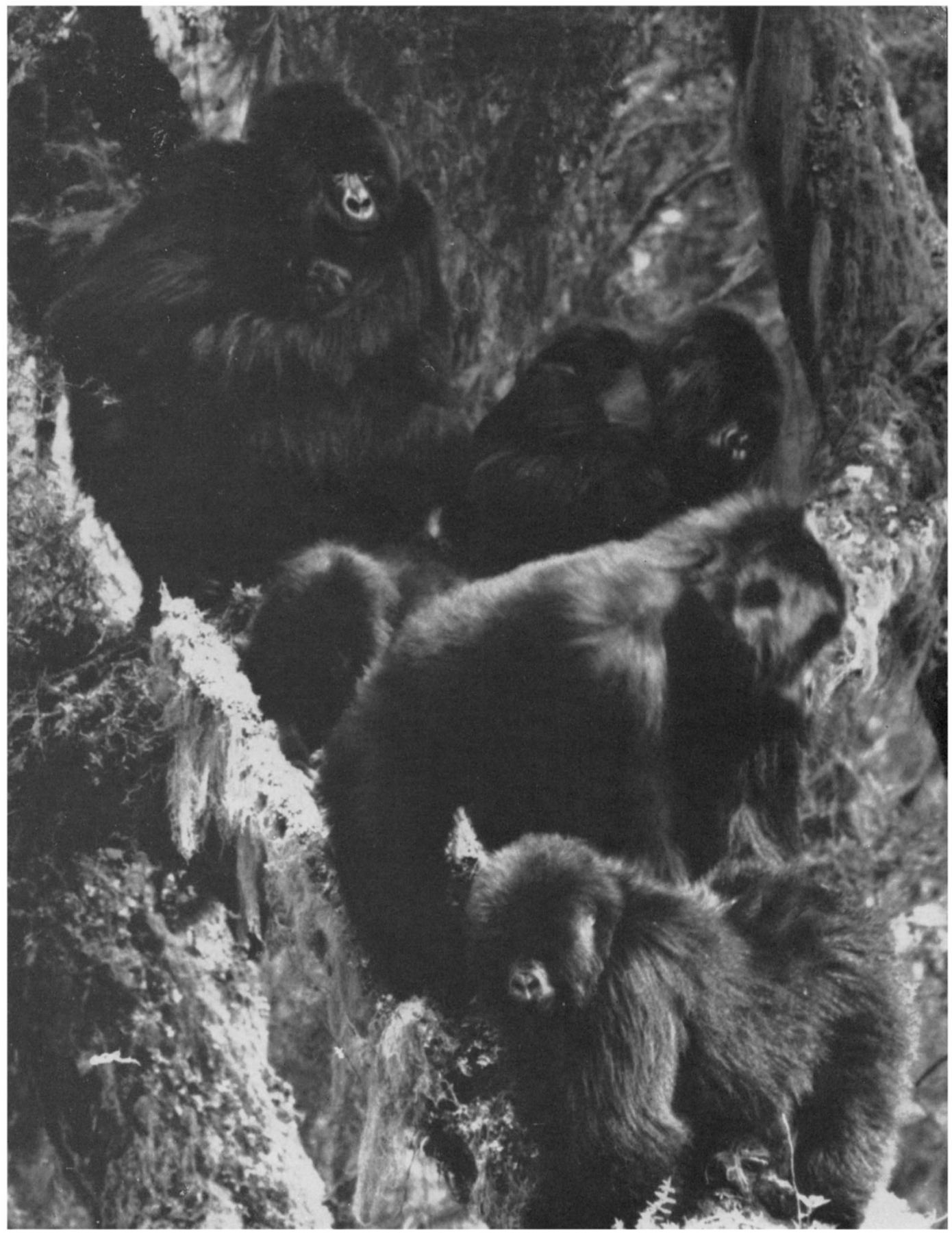

MOUNTAIN GORILLAS IN THE ALBERT NATIONAL PARK

Plate I: Two females, a black-backed male and two large infants crowd on to a tree branch to get a clear view of the photographer, Dr. George Schaller, author of The Mountain Gorilla, reviewed by Sir Solly Zuckerman on page 253 . The photograph is reproduced by kind permission of the publishers. The mountain gorilla was discovered as recently as 1902 by Captain von Beringe, on Mount Sabinio, one of the peaks of the Virunga volcanoes in the Congo. 


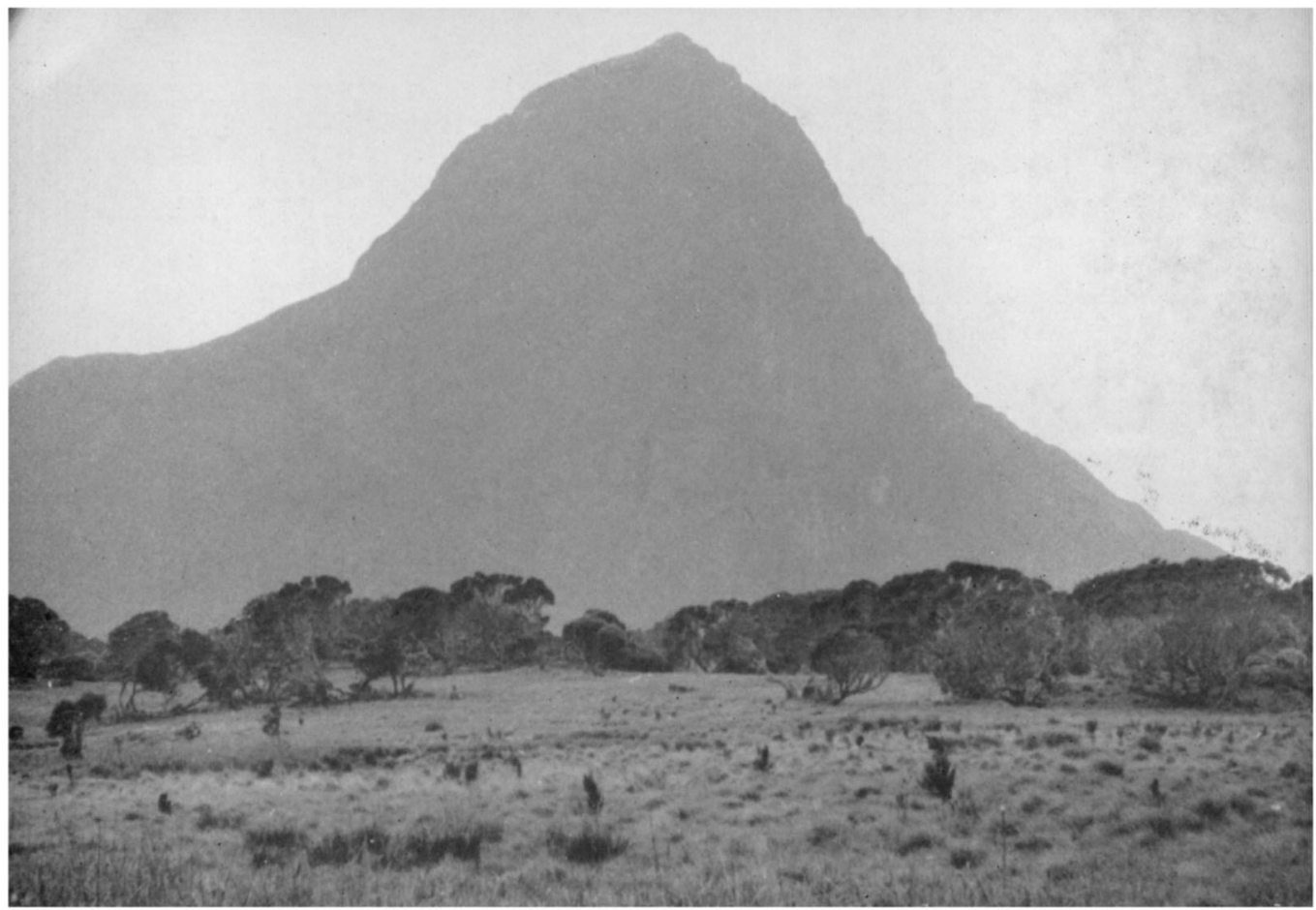

Plate 2 : Mikeno, 4,437 metres, one of the Virunga volcanoes

A VARIETY OF HABITATS IN THE

Photographs by

Plate 3 : Gorilla country. Hagenia forest on the volcano Karisimbi

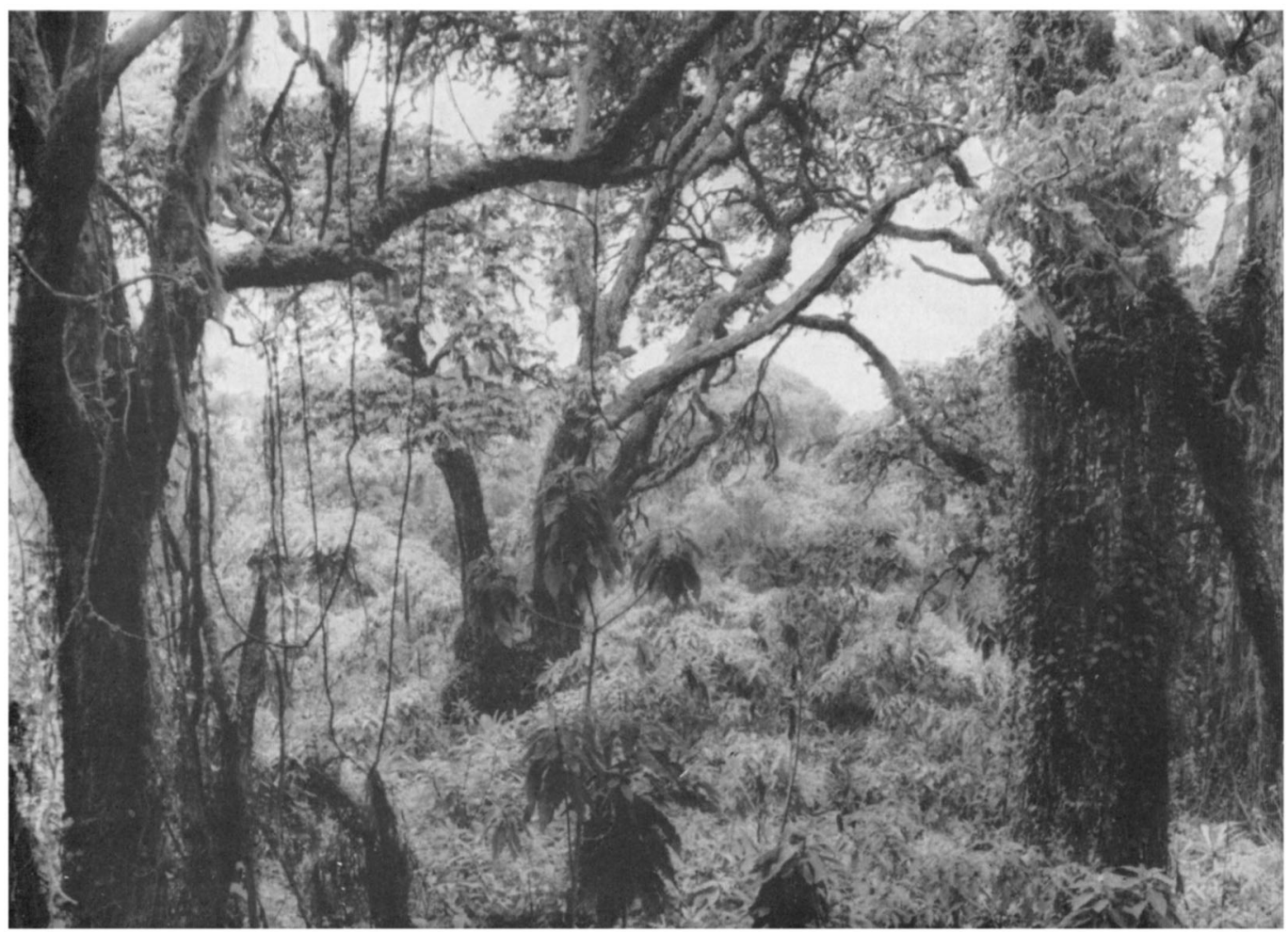




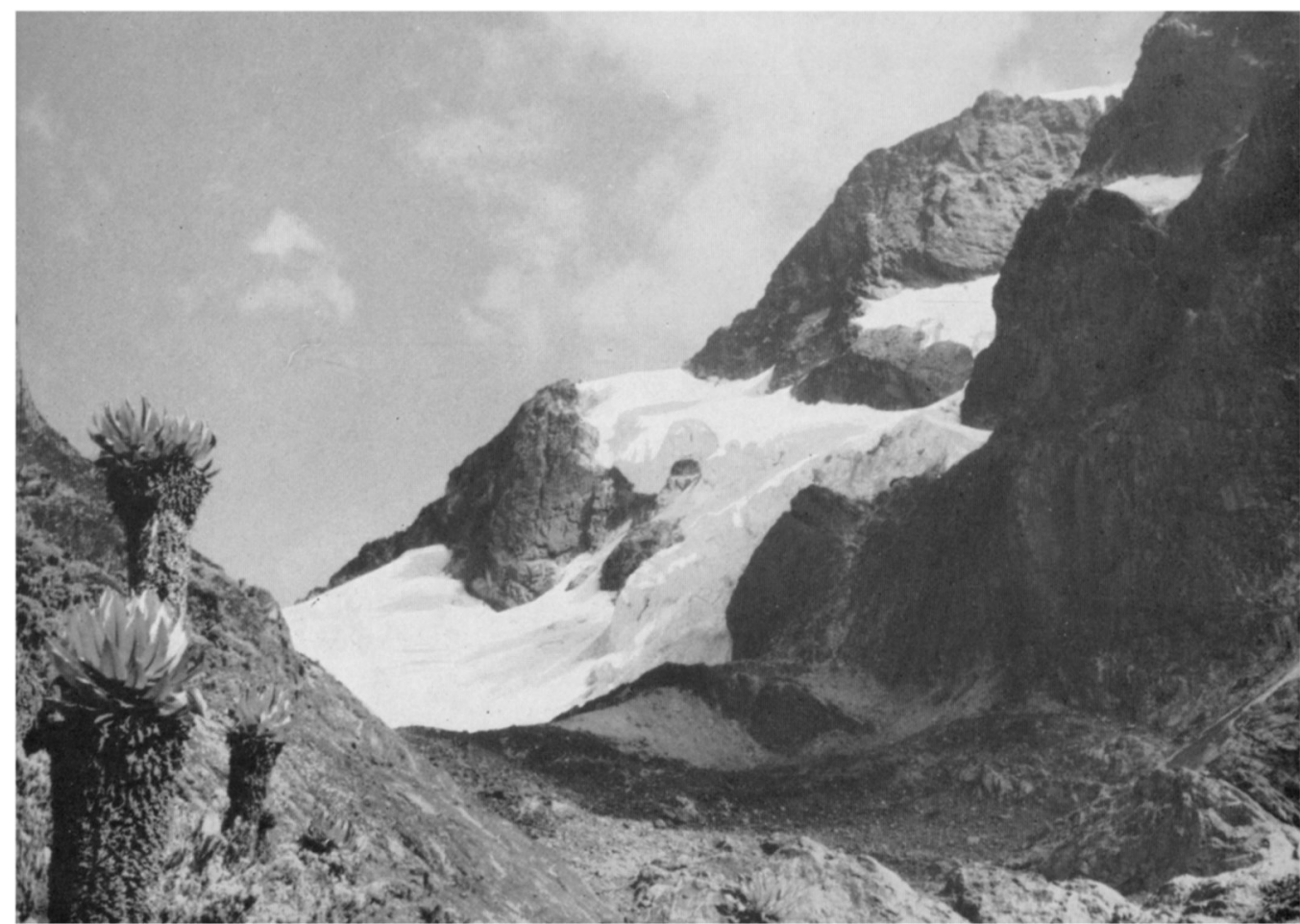

Plate 4: Glaciers and giant senecio on the left at 4,600 metres in the Ruwenzori Mountains ALbERT NATIONAL PARK IN THE CONGO

Kai Curry-Lindahl]

Plate 5 : The Semliki River at Ishango where it flows out of Lake Edward

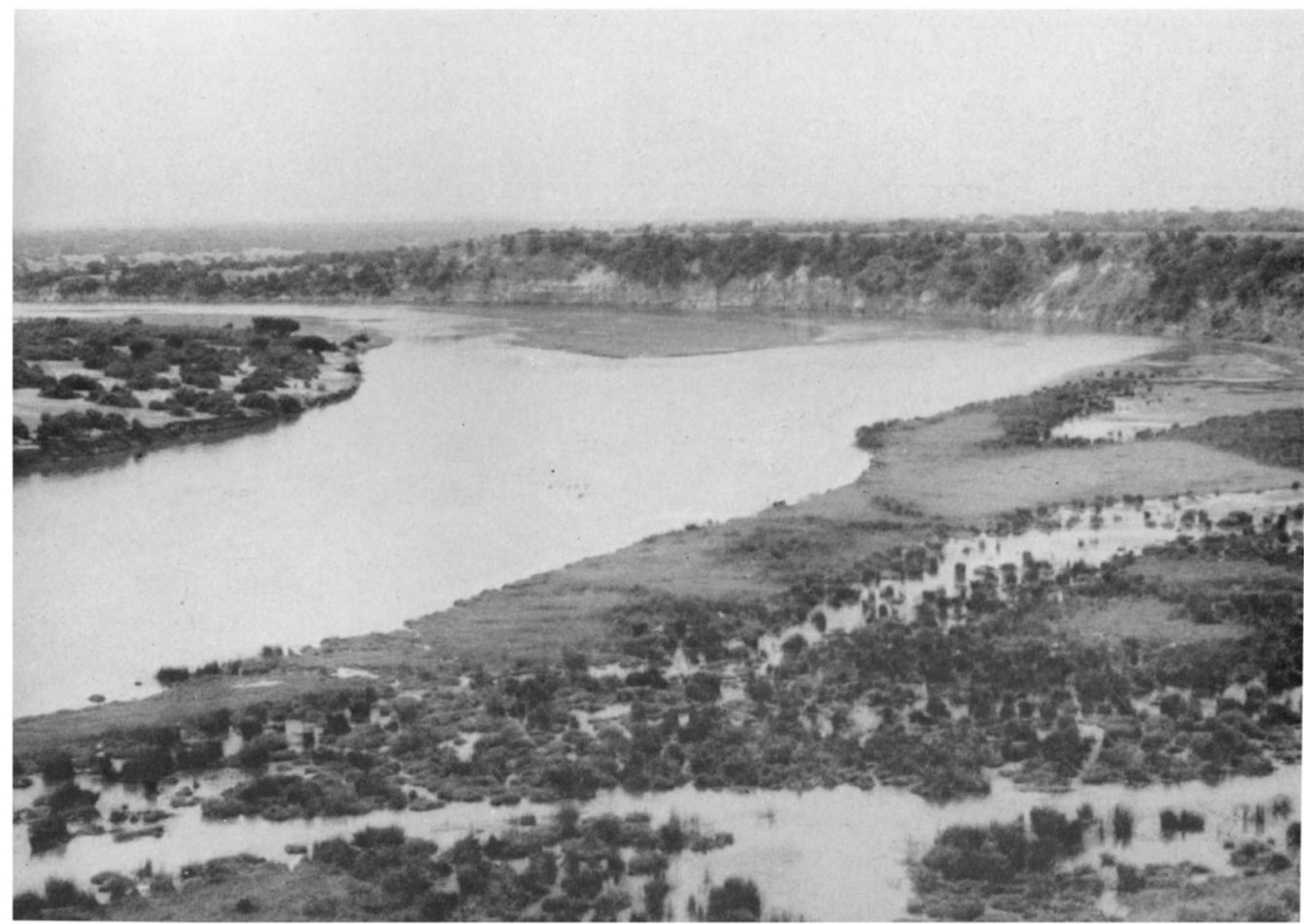




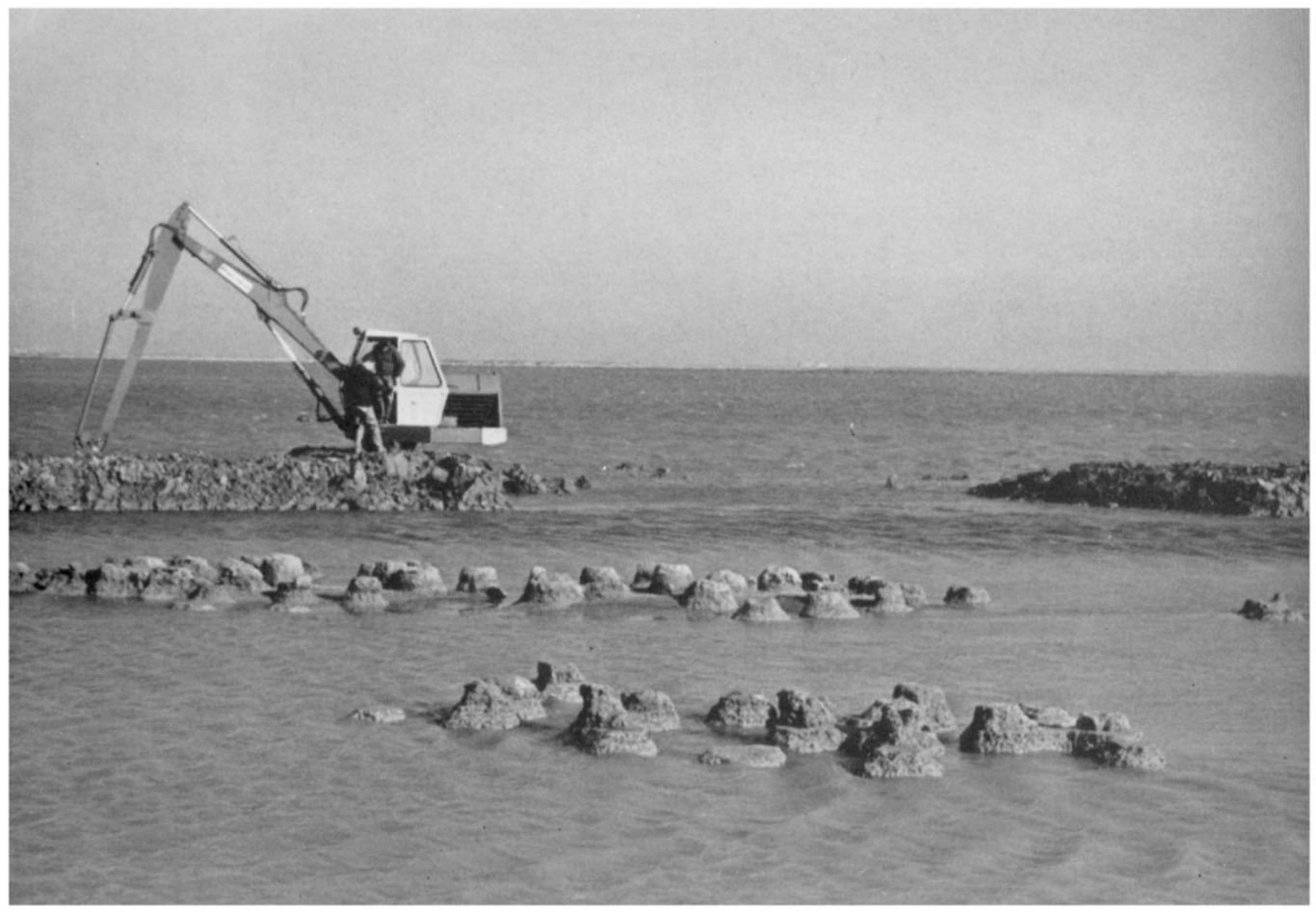

World Wildlife Fund

Plate 6 above : Rebuilding an Island for Flamingos. The World Wildlife Fund gave a grant towards the reconstruction of an island in the Camargue, in the Rhone delta, which had disappeared as a result of the flamingos breeding there. Because the birds had destroyed the vegetation, the soil eroded away, and by 1962 the island had gone. It was particularly suitable for the flamingos' breeding because the Compagnie Salinière de la Camargue kept the salinity and the water level constant, and the flamingos have fajled to rear a single chick in other nearby sites.

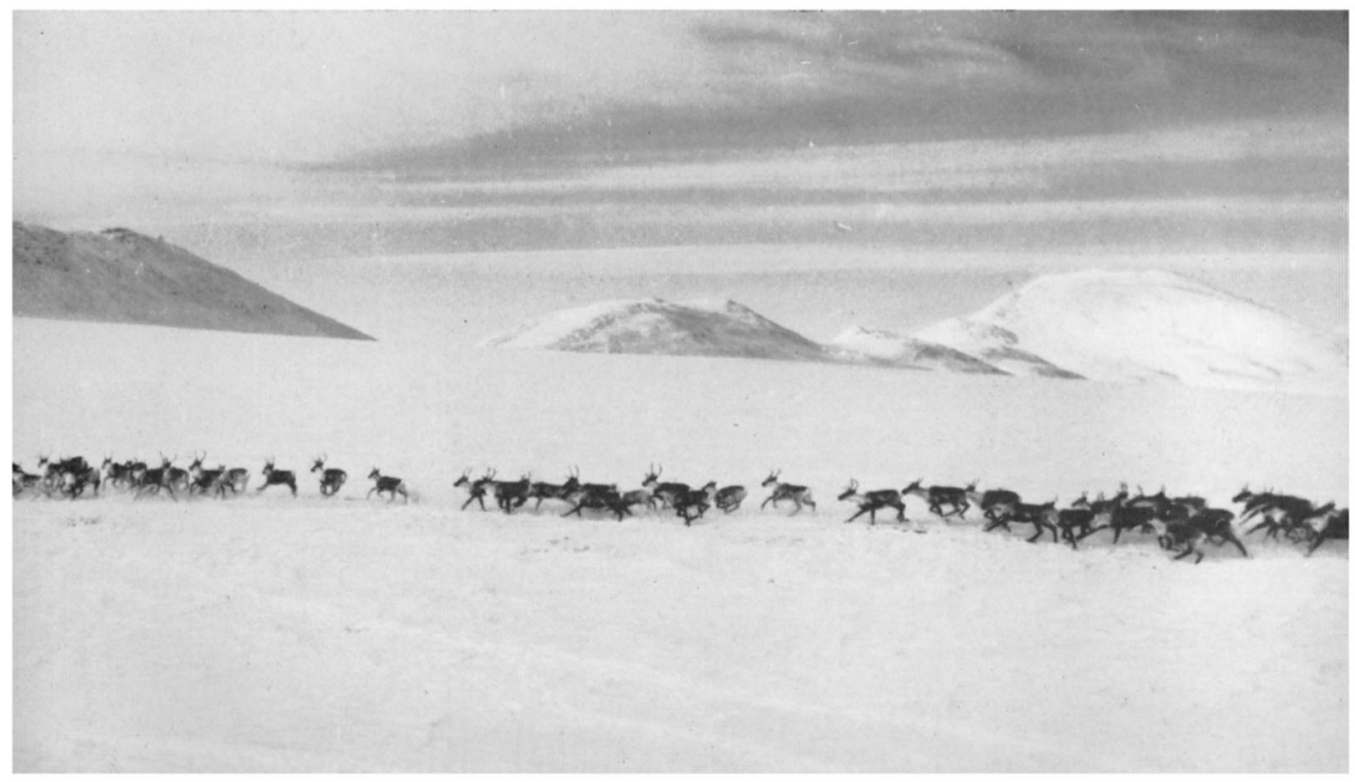




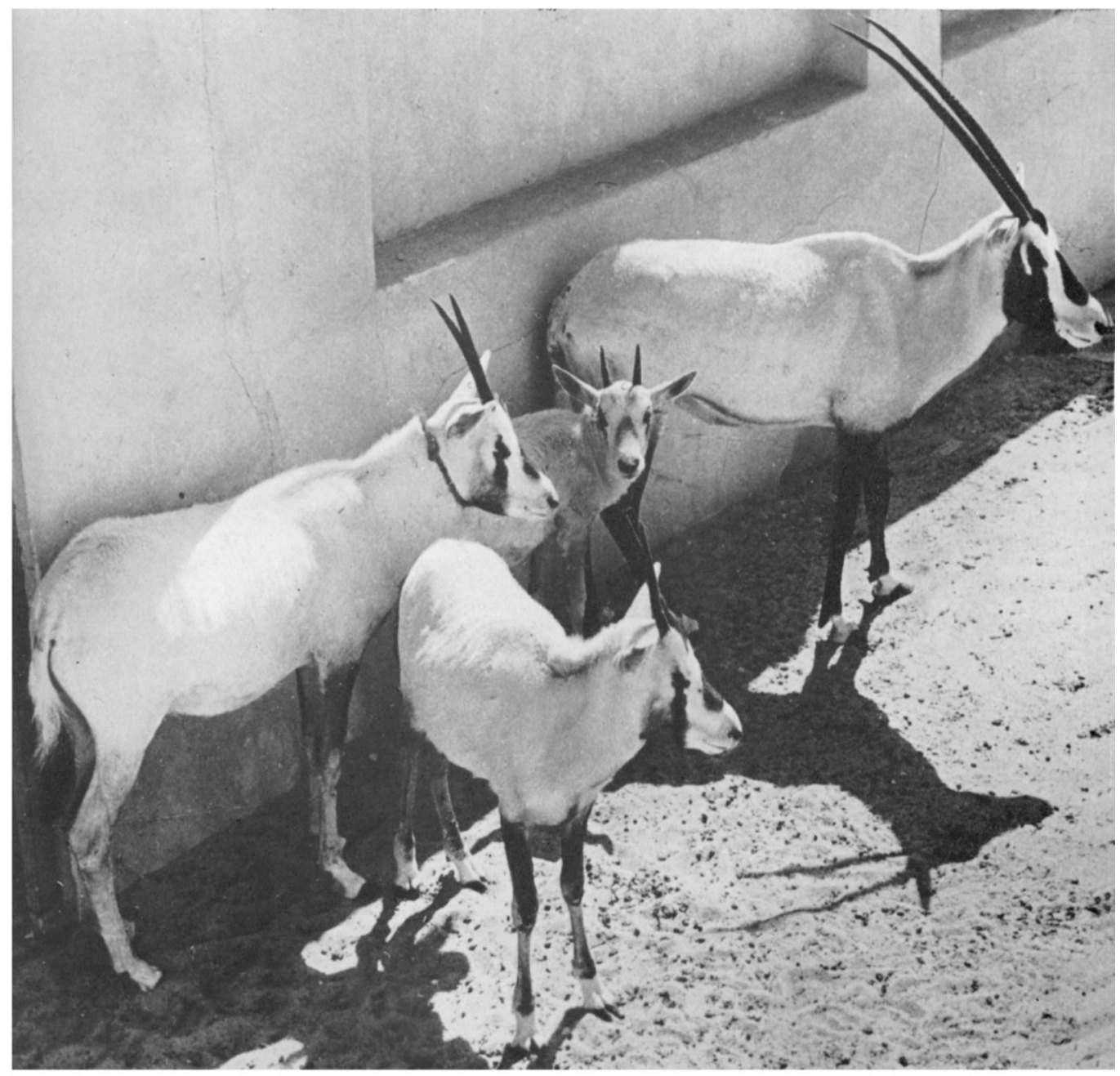

A GIFT FROM SAUDI ARABIA

World Wildlife Fund

Plate 8: These four Arabian oryx, photographed at Riyadh Zoo, in Saudi Arabia, by Major Grimwood when he went to collect them after King Saud had presented them to the World Wildlife Fund, have now joined the herd owned by the FPS and the London Zoo at Phoenix Zoo, Arizona, in the USA. These bring the herd up to eleven, twelve when one of the females, thought to be pregnant, gives birth. In addition to the four pictured here, there are three captured in the FPS's Operation Oryx, and a calf born last October; one presented by the Sheikh of Kuwait to the FPS, and one from the London Zoo and her calf born last May. With this herd it is hoped to breed enough to return some to the wild when conditions are suitable.

Plate 7 opposite : Caribou on the move in Arctic Canada. An article on the serious decline in caribou numbers by John P. Kelsall is on page 240. 


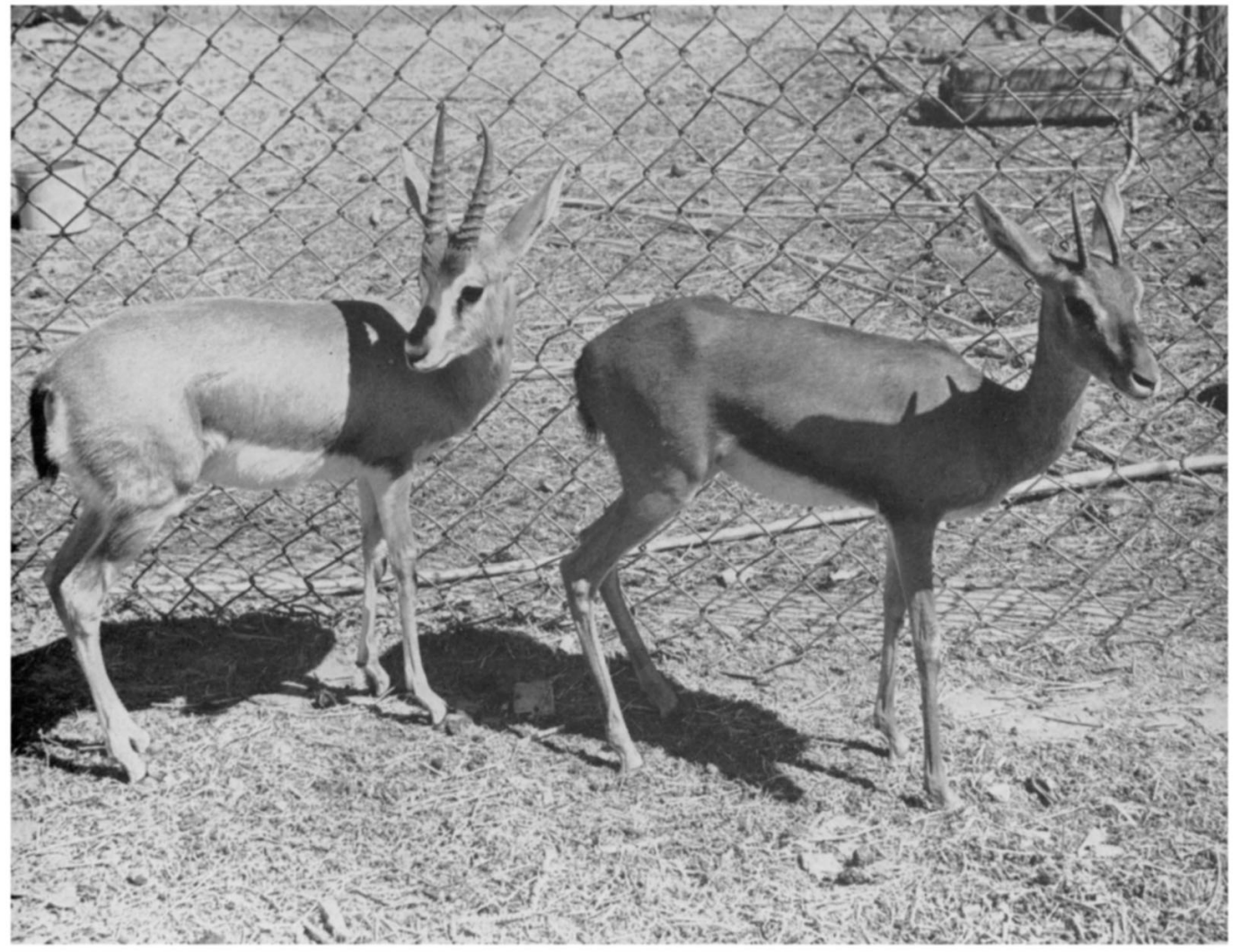

Plate 9 : Arabian Gazelles. They have been almost exterminated in Jordan by motorised raiding parties from neighbouring oil states.

Plates 10 and II : The Palestine Mole-rat... and his teeth, with which he can throw up molehills in a metalled road.

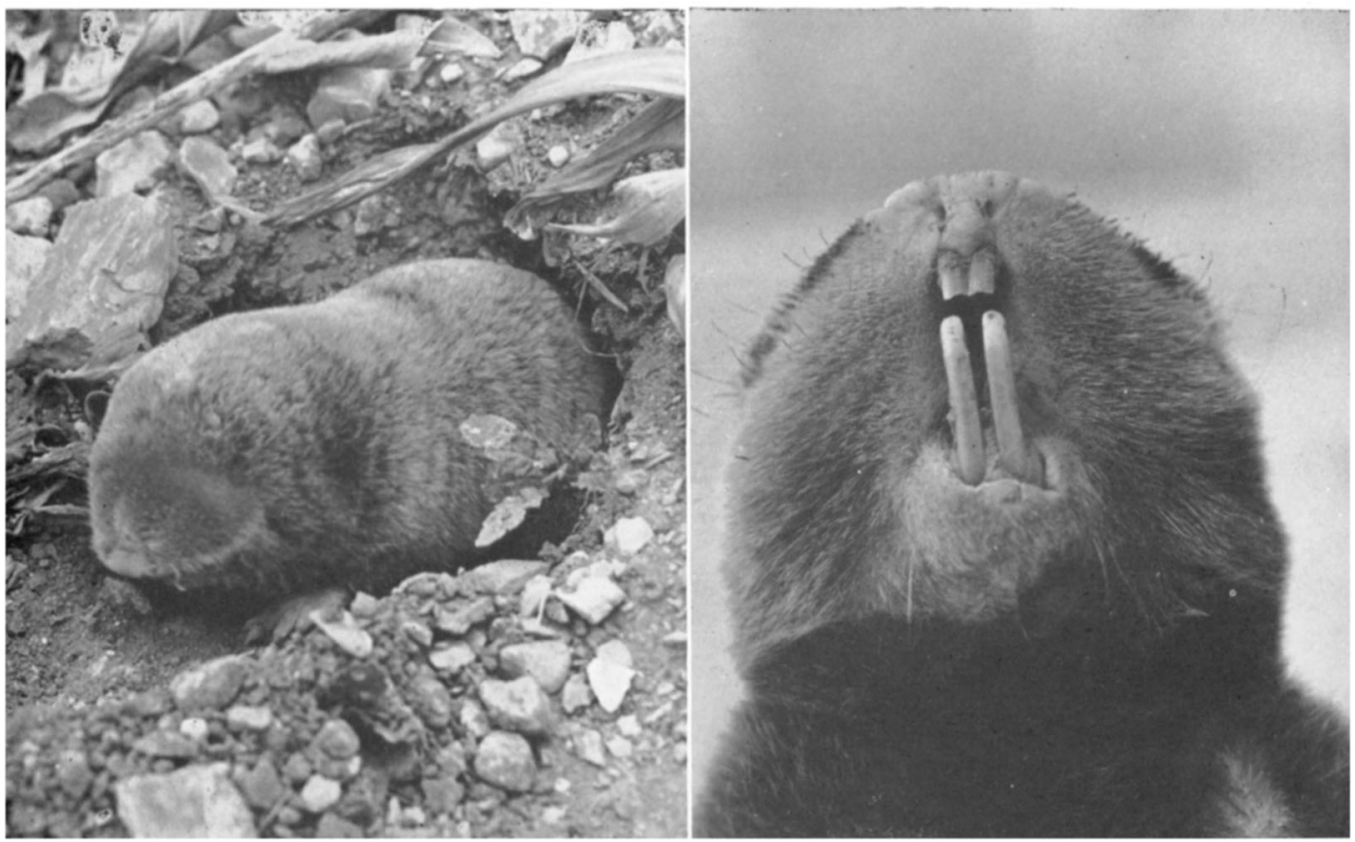




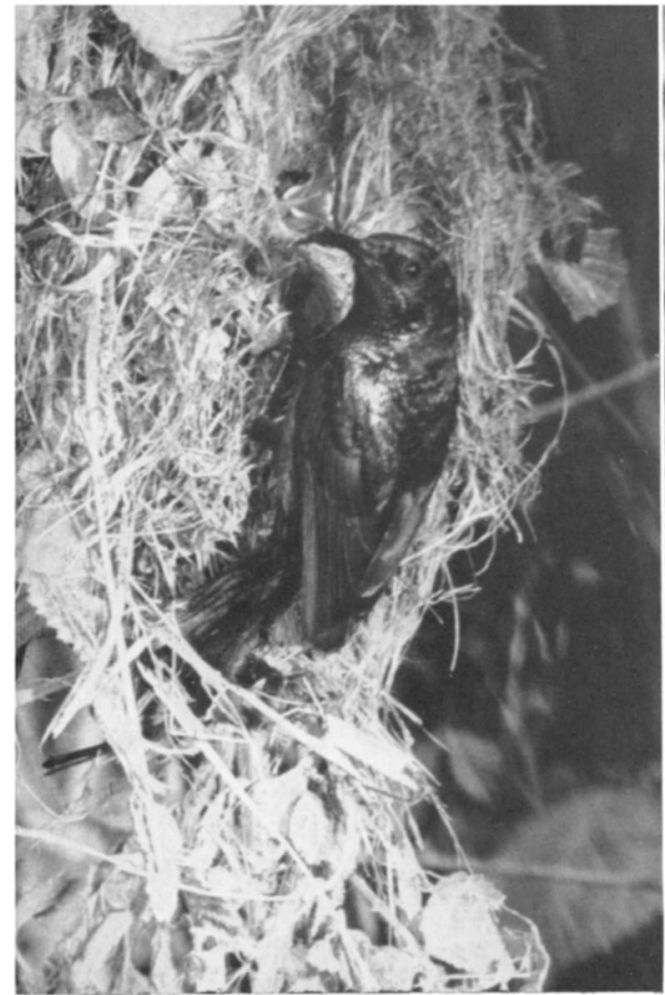

Plate 12 : The Palestine Sunbird has iridescent purple and black plumage and builds a hanging, purse-shaped nest.

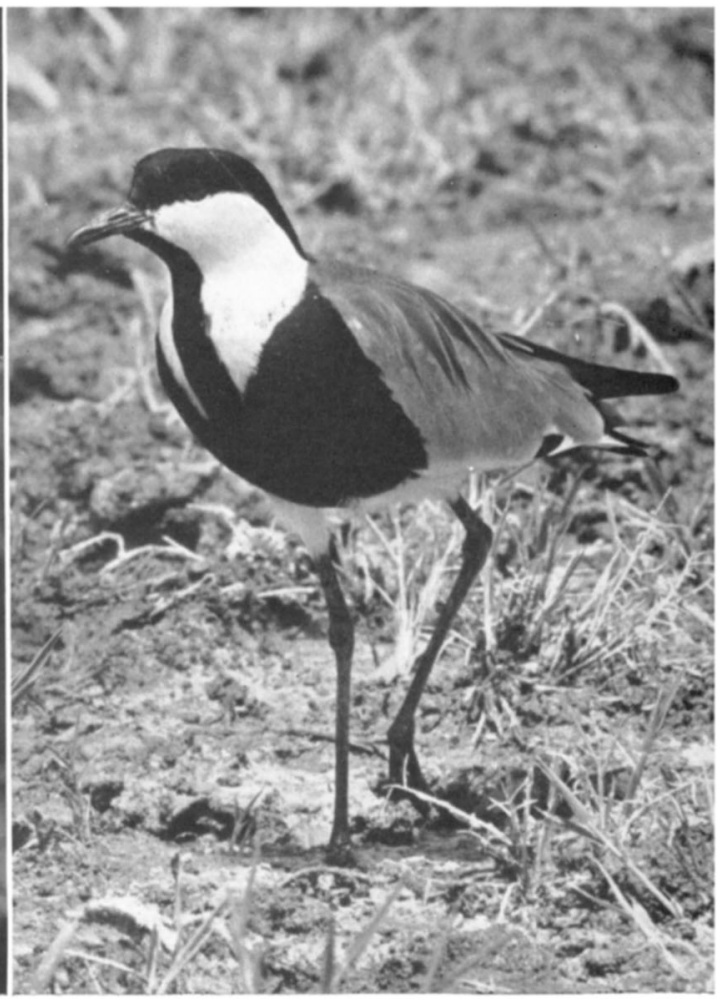

Plate 13 : The Spur-winged Plover has a bony spur on its wing which it uses in territorial fighting.

\section{THE DISAPPEARING WILDLIFE OF JORDAN}

Photographs by Eric Hosking

Plate 14: Hairy-footed Jerboa. The long tail enables it to escape its enemies by changing direction in mid-air while jumping.

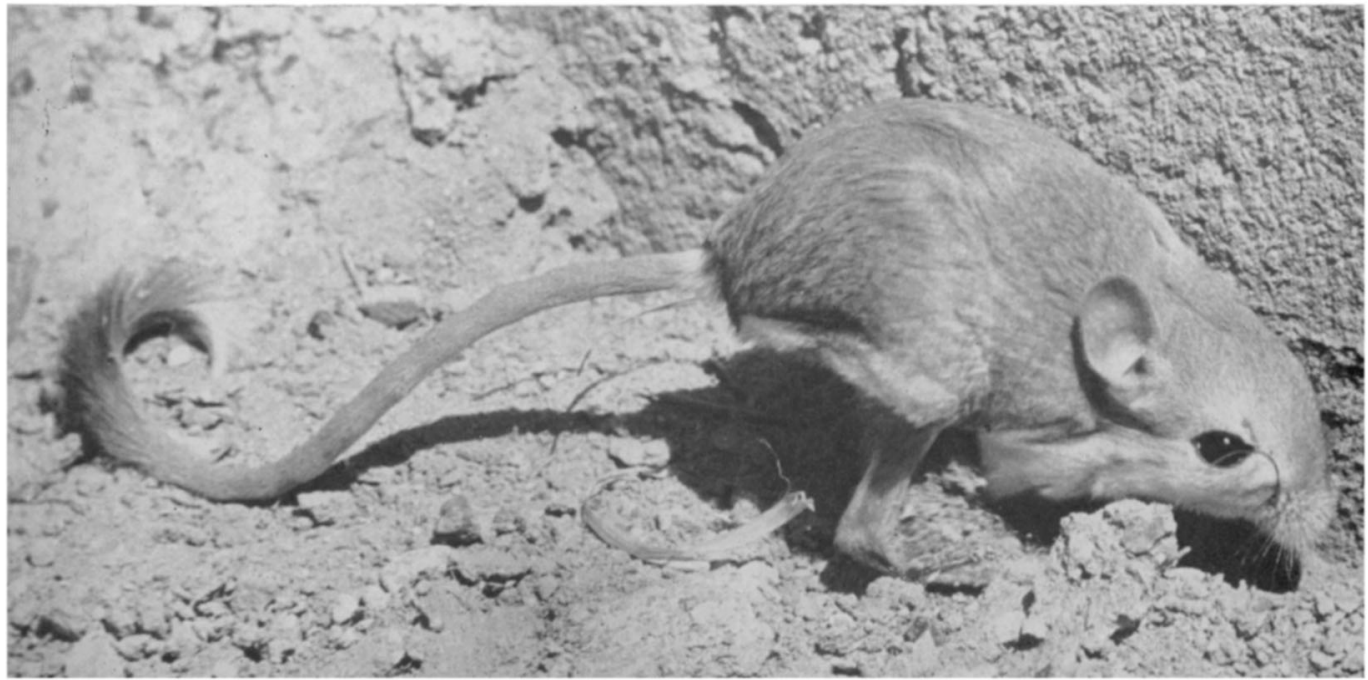




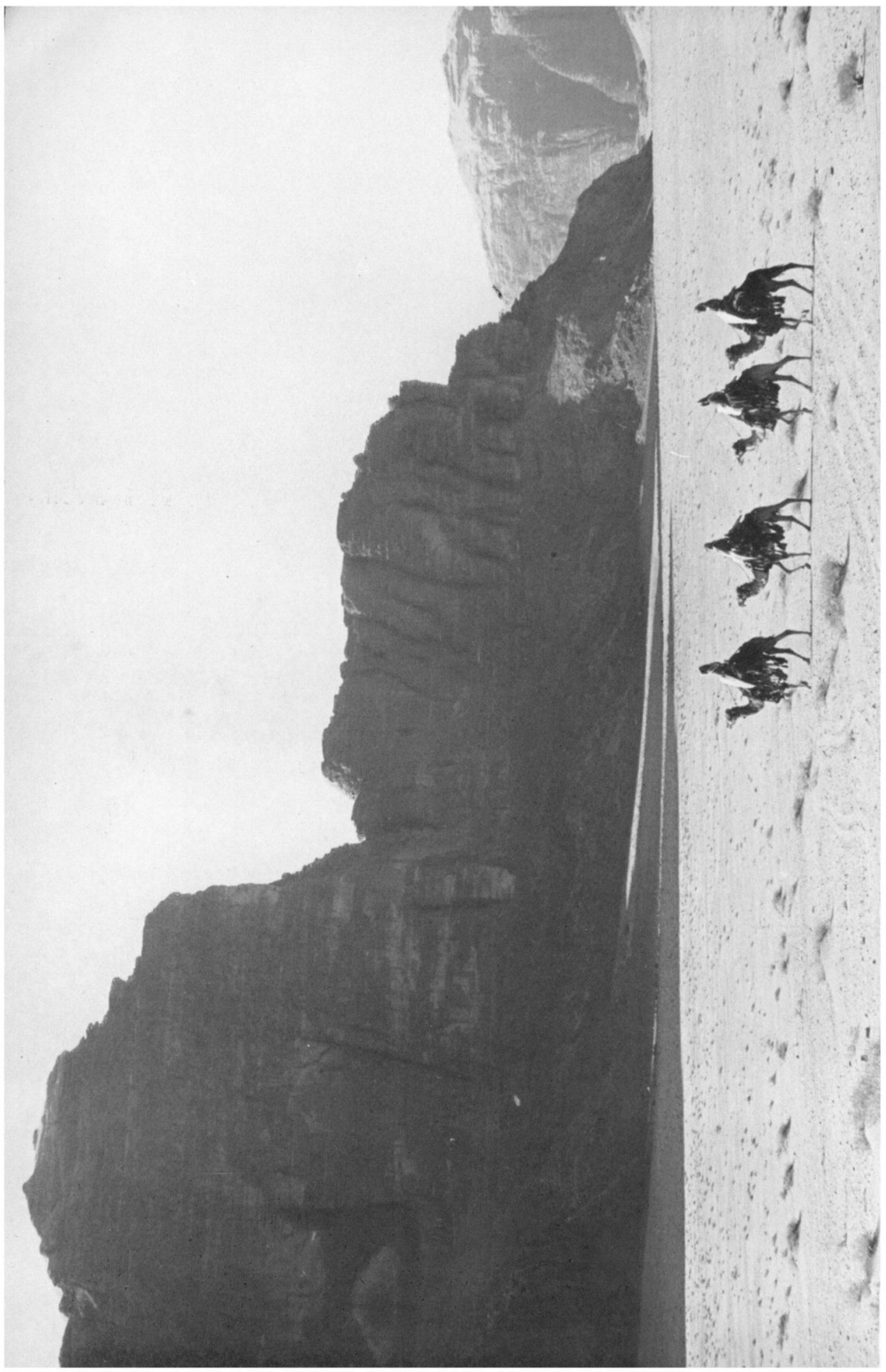


prior to the United Nations decision that all Belgian troops must withdraw. The UN forces did not even try to settle the serious conflict in the Rumangabo area. In this hopeless situation, abandoned by everybody, the administrative staff had no choice but to leave. They have been criticised for that, but nobody familiar with the facts can blame them. After four years, the soldiers still rule the Rumangabo area.

However, one Belgian stayed on. As a scientist, Dr. Jacques Verschuren was considered to be non-administrative and, therefore, accepted. This does not mean that he had a peaceful life. He too was arrested and assaulted, but each time released, and he was able to carry on his planned investigations all over the park. While over most of the Congo there was terror, fighting and disorder, Verschuren and his Congolese assistants and rangers travelled for months in the peaceful wilderness of savannas and mountains in the Albert National Park.

Jacques Verschuren's presence during the most critical period of the park's existence had a considerable moral effect on the rangers and the newly appointed Congolese conservators. Discreetly he advised them in their negotiations with the local political authorities concerning the future of the park-no easy task, for the political instability led to constant administrative changes and discussions had to be started again and again. But by their courage and loyalty, they succeeded in persuading provincial and local authorities and chiefs that the park had to be preserved intact and for this the whole world is grateful to them.

\section{Invasions of Herdsmen and Poachers}

Prior to independence political propaganda in the regions surrounding the Albert National Park had created an atmosphere of hostility towards the reserve, and when independence came local populations thought that they had the right to occupy the national park; poachers moved in, threatening the rangers, who had to defend a boundary of some $1,125 \mathrm{~km}$.; fishermen wanted to establish settlements along the shores of Lake Edward and the Semliki river; herdsmen in Ruanda and Uganda tried to enter the park with their cattle; conflicts among various tribes and between political factions of all kinds went on almost everywhere ; gangs of soldiers were permanently on the move and so on. For long periods, the rangers received no salaries, although Belgium concinued to pay all salaries, including those for Africans, during the first six months of independence. The money was sent to the government in Leopoldville, but there were long delays before it reached the men in the park. Many rangers interpreted the chaos as being the end of their national park's existence.

In this atmosphere the conservators and rangers had to defend not only the idea of conservation principles and policy but also the immense territory of the park. Now, looking back after four years it seems a miracle that they succeeded and that the Albert National Park is still untouched. Moreover, all the patrolling in the interior of the reserve, animal censuses and other routine work continued as they had done for thirty years. There

Plate 15 opposite : Arab patrol in the Wadi Rum, one of the areas recommended by the Jordan expedition for a national park. 
is no doubt that this " national park patriotism" and courageous attitude of the rangers representing different tribes was a major factor in the maintenance of the park. They regarded it as their park, of which they were very proud, and were prepared to defend its forests and animals against all aggressors. One of the rangers, Valère Sauswa, gave his life fighting against aggressors from Uganda, and several others were seriously wounded.

The temporary invasions into the park and the poaching did not seriously affect the reserve. In July-August, 1960, there was some poaching in the northern sector, on the Semliki plain, and fishermen tried to settle near Ishango at the outlet of Lake Edward into the Semliki river. The few unarmed park rangers could not resist the aggressors, but they got help from the Congolese soldiers who expelled the fishermen and cleared out the poachers. Since then poaching has occurred from time to time in this area, which is difficult to patrol, but the effect on the ungulate fauna has been negligible.

Last time I visited the Semliki plain, in September, 1963, there had been some burning, which was not satisfactorily explained by the rangers. At the same time burning occurred on the slopes of Mount Tshiaberimu, between Lubero and the northern end of Lake Edward, in the Albert National Park, an area of great importance, because an isolated population of mountain gorillas lives there. It was explained to me that a chief from the territory of Lubero had moved to Mount Tshiaberimu claiming that the area belonged to his village before the establishment of the Albert National Park. The chief had been arrested by the rangers and handed over to the territorial administrator in Lubero. A case is being prepared, but in the meantime the chief was released, whereupon he returned to Mount Tshiaberimu. The park officials protested, but the territorial administration of Lubero has allowed the chief to remain on the mountain until the case is finished. This is an example of the numerous difficulties which the national park officials have to face. In reality the Albert National Park is the property of the Congolese state, and local authorities have no legal right to allow even provisional settlements in the park.

\section{Fishermen on Lake Edward}

Another area of the park, where there are difficulties at present, is Kamande on the southern shore of Lake Edward. Fishermen have settled there, and the park officials have not been able to get them evacuated. That was the situation in September, 1963. Kamande is one of the most interesting places of the Lake Edward region. The bay of Kanyazi at Kamande probably harbours Africa's densest population of hippos Hippopotamus amphibius. Working there in 1959 I counted 192 hippos in a sector of about $500 \mathrm{~m}$. when walking along the shore close to our camp (Curry-Lindahl, 1961). In the whole bay a two days' count made from a boat, a less accurate method, showed a minimum of 741 . The region is also extremely rich in other mammals and birds, so it is highly desirable that the fishermen at Kamande should be evacuated as soon as possible and that no new fisheries are established in other parts of the national park in addition to Vitshumbi and Kiavinionge, the two authorised fishing villages, 
which have operated for a long time on the Congolese side of Lake Edward. The commercial fisheries within the Albert National Park are interesting as an example of how the exploitation of an aquatic natural resource can, when properly organised, be carried on side by side with a "strict nature reserve" on the surrounding shores. The effect of the fishing villages on the vegetation of the shores they occupy are detrimental but unavoidable, so it is important that the fisheries should have only these two bases, which are carefully controlled.

The people are not allowed to introduce any plants or cultivate the soil, but they have the right to keep goats, which must be kept in the vicinity of the village. There is a "goat boundary ", and goats rarely stray beyond it, because they are permanently watched. However, goats, wherever they occur, always increase in numbers, so they constitute a serious problem which in the long run can only be solved by either a limitation of their numbers or their complete elimination.

\section{Country of the Mountain Gorillas}

The eastern sector of the Virunga volcanoes with their populations of mountain gorillas, one of the most important areas of the park, is unfortunately also the most difficult to administer, because a portion belongs to Ruanda, the country in tropical Africa with the densest human population. In addition, since Ruanda recently achieved independence, the political situation there has been unstable. With the terrific population pressure it seems inevitable that cultivators and pastoralists will invade the slopes of the Virunga volcanoes, which would mean complete destruction of the forests and a serious threat to the existence of the gorillas. However, the Ruanda government also has hitherto respected the boundaries of the park and is most co-operative in this respect, but it has no effective control of the herdsmen and their livestock, which have penetrated into this sector of the park. The goodwill of the Ruanda Government concerning the national parks has been clearly demonstrated by its firm actions to maintain the Kagera National Park in the north-eastern corner of the country. No doubt they will in the long run also succeed in the Virunga volcanoes.

The most serious invasion by Watutsi pastoralists and Watutsi cattle took place in 1960, when almost the whole area of the Ruanda part of the national park was affected. Trespassing into the Congo occurred, and large parts were grazed. The situation was very alarming when, in August, 1960 , the Congolese park rangers intervened at two raids. They confiscated more than sixty cows, shot about a dozen, and drove the Watutsi and their cattle out of the Congo side of the park. Since then the Watutsi have not attempted to reinvade the Congolese part of the volcanoes, although the Ruandesian part of the park is still partly occupied by grazing cattle. This is actually the most serious problem in the Albert National Park, and it can hardly be settled satisfactorily before administrative order is restored.

\section{Help From Outside}

The financial situation is another problem. The central government in Leopoldville is anxious to preserve the national parks to continue the policy 
of strict or partly strict nature reserves and to carry out scientific investigations. Salaries are now paid to the personnel. The quality of the buildings for tourists and administration is still excellent and in this respect the park officials have done a wonderful job. At whatever time one turns up at Rumangabo or at the Rwindi Camp or Ishango everything is in perfect order and very clean, and the Congolese are anxious to maintain this high standard. Boats and other technical field equipment, however, are less satisfactory, though much appreciated and valuable help has been received from international organisations such as UNESCO and the World Wildlife Fund, as well as conservation and research organisations in Belgium, Germany and the United States. This material assistance has been a moral encouragement for the park officials as evidence of the importance that international and foreign conservation organisations attach to the park.

In September, 1963, Dr. Harold J. Coolidge, Chairman of the International Commission on National Parks, as well as representatives of important American foundations and some members of the Commission were invited by the Congolese Government to visit the Albert National Park and discuss different problems with representatives of the Ministry of Agriculture in Leopoldville and the national park officials in the Kivu. A series of meetings and informal discussions took place at the park's different headquarters at Rumangabo, Rwindi and Ishango. Meetings were arranged with the rangers in the various sectors of the park. Field trips clearly demonstrated its intact state and the usual astonishingly rich animal life. The ungulates' lack of fear of human beings showed once again that they had not been disturbed by poaching or irregular visitors. One of my tasks during these trips was to introduce its natural history and ecology to the foreign guests. It was an easy task because the park spoke for itself in a convincing way. Most, perhaps all, members of the party agreed that the truly wild landscapes of the Albert National Park surpassed everything they had seen in Africa.

\section{Co-operation With $U_{g a n d a}$}

Several vital questions were discussed with the Congolese authorities regarding the park and its future: general policy, economy, research, tourism and the necessity of considering the Albert and the Queen Elizabeth National Parks as an ecological unit, with close co-operation between the Congo, the Ruanda and Uganda. New statutes for the Congolese national parks are under preparation by the Government, and it has been decided that the Albert National Park will retain its ancient and well-known name. Later, at its meetings in Nairobi, the Commission agreed that this park should be recognised as the most important national park in Africa, and should have priority in efforts of the Commission to save the national parks.

Because for more than thirty years there has been no human interference or management whatsoever of the larger mammals in the Albert National Park and there has been no artificial burning, except since 1960 in a narrow boundary sector of the Ishasha plain alongside the Queen Elizabeth Park, where burning is frequent, it is very interesting to analyse the population dynamics of the mammals, as was done by Bourlière and Verschuren (1960). 
It should be added that since 1960 there has been no decline as far as we know in the numbers of any mammal or avian population in the park. There are still no signs of degradation either of the environment or in the populations of hippos in spite of the very high number and density of that species (cf. Curry-Lindahl, 1961, Verschuren, 1964). The hippo population of the park is certainly very large (about 20,000) and the animals consume enormous quantities of food, but the vegetation surrounding lakes, pools and rivers apparently stands the grazing. The hippos are well fed and in excellent condition, and there is probably an established equilibrium with only minor fluctuations. It is scientifically interesting to compare the consequences of the intensive cropping of hippos in the neighbouring Queen Elizabeth Park in Uganda with the policy of strict preservation in the Albert Park, and it is remarkable and cause for gratitude that the Congolese authorities maintain the policy of strict protection in spite of the fact that their neighbours extensively harvest the hippo populations in the Queen Elizabeth Park. The only animal in the Albert Park to worry about at present is the gorilla, due to the unstable situation in the Ruanda, but fortunately these nomadic apes still have large areas to roam in the Congo part of the reserve, where they are well protected.

\section{Another Belgian Who Stayed}

In the Garamba National Park, also a strict nature reserve, in the Congo's province Orientale, $M$. Albert Ory, who was the conservator of this national park, stayed on at his post despite all kinds of physical and moral difficulties. The fact that some months ago he was appointed by the Congolese Government as technical adviser of the National Parks of the Congo, is a testimony that his remarkable courage and capacity are greatly appreciated by the authorities, as well as by all those who are concerned about the maintenance of the Congo's national parks.

Even though the Government of the Congo has stated its firm intention to maintain the national parks and to continue scientific investigations there and also to create a new park, the Salonga National Park, in the equatorial lowland rain forest, it must be realised that the future of the Congolese national parks depends entirely on the political and economic situation of the country. But as the Congo national parks have survived the first three extremely difficult years after independence, one may presume that the most critical period is over, and that the only integral nature reserve of this size will continue to be preserved by the Congo Government.

\section{LITERATURE CITED}

BOURLIĖre, F., and VERSCHUREN, J., 1960. Introduction à l'écologie des ongulés du Parc National Albert. I. Exploration du Parc National Albert. Mission F. Bourlière et J. Verschuren, 1959.

CuRRY-LindaHI, K., 1961. Contribution à l'étude des vertébrés terrestres en Afrique tropicale. I. Exploration du Parc National Albert et du Parc National de la Kagera. Mission K. Curry-Lindahl (1951-52, 1958-59).

Verschuren, J., 1964. Que sont devenus les Parcs Nationaux du Congo et du Ruanda? Zoo, 29, 129-134. 